\title{
THE INFLUENCE OF REGIONAL CULINARY TRADITIONS ON THE ATTRACTIVENESS OF AGROTOURISM OFFER
}

\section{PIOTR DOMINIK, ${ }^{1}$ JÓZEF GROCHOWICZ, ${ }^{2}$ MICHAŁ KOSKOWSKI ${ }^{3}$}

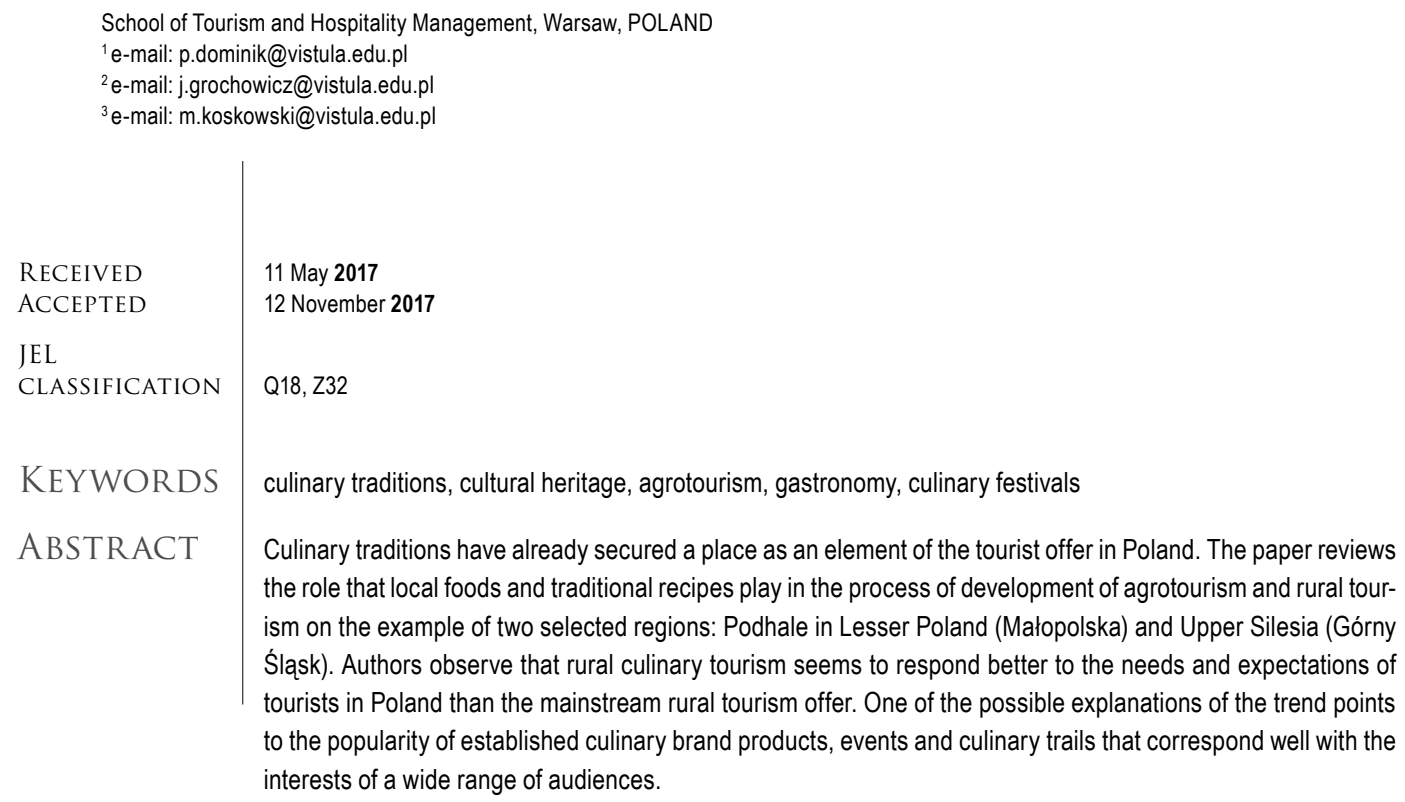

\section{Introduction}

The aim of the paper is to analyse how culinary traditions affect the development of agrotourism offer in selected regions of Poland. It also sets out to resolve to what extent the inclusion of culinary traditions in rural tourist products increase the attractiveness of those products. For the benefit of the paper two particular regions have been selected that stand out with regard to their gastronomic traditions: Podhale and Silesia (Ślask). Podhale is a very specific region, even on a national scale, as it has been settled for centuries by the same people, which has resulted in a very strong local cultural identity and a feeling of relative sovereignty, as well as a striking continuity of 
inheritance. Silesia, in turn, was subject to a number of demographic changes in the $20^{\text {th }}$ century. Geographically, Silesia is divided into the Lower and the Upper Silesia. However, both the popular notion of Silesian culture and the local cultural identity - including culinary traditions - are practically limited to the Upper Silesia and the Opole region, i.e. the former Polish-German borderland, where local traditions remain an important binding factor for local communities, despite the socio-economic upheavals that have affected the region since 1945. The methodology chosen for this article consisted predominantly of content analysis of relevant literature and a critical analysis of selected, major tourism products based on culinary traditions and local foods, typical for the studies regions.

\section{The phenomenon of agrotourism}

The term agrotourism contains two elements: agro, and tourism. The Latin prefix agro derives both from an Old Greek agros, meaning 'rural', and agronomos, which was a title of the person who acted as a 'farm manager' (Sznajder, Przezbórska, 2006, pp. 15-17). Agrotourism is usually defined as a form of tourism and recreation that occurs in the countryside in a place of a distinctively rural character, where both the hospitality services and the accompanying activities are connected with farming and based around farms and their surroundings. There is a vast array of activities available to agrotourists, ranging from cultural, through adventure and qualified, to educational (Krupa, Soliński, 2004). Typically, agrotourism is dependent on local entrepreneurship and creates employment for local community members, in particular involved in rural crafts, crop cultivation and animal husbandry, and often serves as an additional source of revenue for farming communities (Kryński, 2003, p. 125).

There is a popular notion that agrotourism is synonymous with rural tourism, however the latter term has a broader meaning that encompasses all kinds of tourism that "take place in the countryside, are appropriate for local conditions, and utilise local assets" (Dębniewska, Tkaczuk, 1997, p. 15). The fundamental feature of agrotourism, in turn, are annual holidays and short, weekend stays at working farms of different kind: those specialised in crop or fruit production, but also at fishing farms etc. Agrotourism offer varies greatly and features strong regional characteristics, but in general remains relatively limited in scope as compared with city-breaks.

Promotion and development of agrotourism is usually supervised or arranged by local and regional agrotourism associations and destination management organisations (DMOs), whose members are also local farmers or representatives of farming communities. Promotion is however rarely matched by equally well developed distribution channels. The latter remains also true for generic rural tourism stays in accommodation other than that linked directly with agrotourism, typically available in the mountain regions and at the seaside. Rural tourism offer can often be limited to overnight stays, too.

Recently, both agrotourism and rural tourism in Poland have suffered a year-on-year decrease in numbers of visitors and a marked decline of business. For a number of years since the World Financial Crisis of 2008-2012, a much greater growth of both the tourist demand, and of the accommodation offer has been the feature of city tourism, which remained largely unaffected even by the falling tourism participation rates and the reduced number of trips per year recorded in Poland. It warrants an additional hypothesis that the quality and attractiveness of the tourist offer in the Polish countryside generally do not meet the evolving needs and expectations of contemporary tourists.

In this context it is interesting to note the growing reputation of culinary tourism in Poland, based on local gastronomic traditions, rural crafts and local foods (Byszewska-Dawidek, Janusiewicz, 2010). The connection between culinary traditions and rural tourism has been made by many authors. D. Orłowski (2016) concludes, 
drawing from a number of observations in this field, that rural areas offer vast opportunities for the creation of a variety of tourist products based on cultural and natural assets, and agrotourism in particular seems well suited to benefit from the diversity and wealth of regional culinary traditions. Travelling offers a specific setting in which one seems more eager to cross his personal or cultural barriers in order to get to know local cultures, including their food. It does not happen in the controlled, luxurious setting of a restaurant but amongst the vibrancy and sometimes chaos of a village market or a farmyard. It has been noted that majority of the traditional and regional foods is available almost exclusively directly from their producers or at agrotourism farms (Krupa, 2010; Woźniczko, Orłowski, 2009; Orłowski, 2016). Apart from being an additional promotional assets for farm-based tourism businesses, traditional foods have an economic potential. There is a noted, supra-regional demand for quality rural gastronomic products and, given sufficient organisational and financial support, the production of local foods could just as well turn from a hobby or passion into an income-earning activity (Krupa, 2010). Some producers have already spotted this opportunity. One of the suggested ways to promote the development of rural gastronomic crafts is membership of the European Network of Regional Culinary Heritage - ENRCH (Jęczmyk, Maćkowiak, Uglis, 2014). Authors also observe that ever since the link between tourism and traditional gastronomy was firmly established in Europe the early 2000s (Hjalager, Richards, 2002), culinary tourism in the Polish countryside has owed its burgeoning popularity to the ever larger number of thematic culinary trails, such as the Wine Trail, and of culinary events, such as the Apple Festival, the Bread Festival etc. A number of popular, brand products have resulted from this trend, including the Lesser Poland Fruit Tree Trail (Małopolski Szlak Owocowy), the Kurpie Honey Harvest (Miodobranie Kurpiowskie), the Lesser Poland Herb-scented Villages (Małopolska Wieś Pachnaca Ziołami), the Carp-fish Valley (Dolina Karpia in Zator), the World of Camomile (Kraina Rumianku), and many others.

Evidently, the proces of building the market for traditional foods is already under way in Poland, however, some authors observe that it might be difficult to strike the balance between development, which often goes hand-in-hand with innovation, and tradition. It has to remembered that indeed it is the tradition, along with time-tested customs, rituals and an old-fashioned lifestyle, that tourists typically associate with authenticity, quality and uniqueness of culinary heritage (Kuźniar, 2010; Puciato, Woś, 2011).

\section{Tourist value of traditional foods in selected regions}

Rural tourism and agrotourism in the Lesser Poland Voivodship are considered one of the most important forms of tourism in the region. The current and future areas of agrotourism development can be found throughout the voivodship, with the exception of the large cities of Kraków, Tarnów, and Nowy Sacz. Areas particularly suitable for agrotourism expansion have been identified at the feet of the Tatra Mountains in Podhale, and also in Beskidy ranges: Makowski, Sądecki, Niski; also in the Wieliczka and Ciężkowice Hills, in the Gorce Mountains, around the Babia Góra Range, and around the Jurassic hills and crags between Kraków and Częstochowa (Kierunki rozwoju turystyki, 2008).

The regional cuisine is often seen as an important element of the total rural tourism product, even though culinary tourism also features as an autonomous tourism category in the voivodship. A vast variety of tourist products in the Lesser Poland are linked directly or indirectly with regional foods. For instance, monasteries and abbeys seem a particular regional asset that not only provides a tangible link to the glorious past through their works of art and historic buildings, but they also facilitate an intangible connection with the rich culinary tradition of the region through a range of food-related products and activities. Tourists are therefore lured to Szczyrzyc in the charming 
and steeped in legends Beskid Wyspowy by both the architectural heritage of a former Cistercian abbey, and by the role that it played - according to the centuries-old chronicles - in the production of a thirst-quenching beverage called cerewizja, a mixture of malted grain, hops and chicory. Recently, in cooperation with the brewery 'Belgia' the traditional drink has been developed into a Trappist-style beer marketed under the apt name Frater. Additionally, the Abbey farm keeps cows of a traditional breed that produce high quality milk (Tomczyk-Miczka, 2007).

In the south of the Lesser Poland region, along the border with Slovakia, are stretched vast mountain ranges that are home to a highlander cuisine - simple, hearty foods based on staples such as sheep cheese, sauerkraut soup and potato pancakes known as moskole. The today's highlanders lifestyle is not much different to that of their forefathers. They continue the tradition of sheep grazing throughout the Summer on high pastures and mountain meadows under the watchful eye of experienced herders and their helpers. The sheep are walked for significant distances, changing pastures as and when needed, until they are brought back home to villages in late September. During this period, tourists can sample the traditional hard, salted and smoked sheep cheese of various sizes and shapes by visiting a growing number of sheds and huts, whose construction and maintenance has been also recently co-financed by the European Union in the move to support local pastoral traditions (Tomczyk-Miczka, 2007).

A yet another example of a successful agrotourism product based on a culinary tradition are homemade strong alcoholic drinks produced in Łąck, based on plums, as well as a pine needles, fruit juice and honey mixture, produced in Łazy. Fruit harvest remains a tourist attraction throughout the Lesser Poland region, too, culminating in September, as does an opportunity to witness the production of fruit juices, such as those manufactured in the traditional fruit press in Zarzecze.

Culinary events treat tourists to excellent local dishes in such agrotourism-famous gminas (the smallest administrative unit in Poland) as Mszana Dolna, Niedźwiedź, Dobra and Tymbark in the Limanów district, and Żegocin, Łapanów and Lipnica Murowana in Bochnia district of the Lesser Poland voivodship (Tomczyk-Miczka, 2007).

The Silesian voivodship authorities also support the development of rural tourism and agrotourism, however culinary aspects play a lesser role in the tourism promotion in this case. In general, it is assumed that the agrotourism product in the voivodship is a natural combination of tangible and intangible assets linked with farming. There are, however, several rural areas officially delineated as particularly suitable for the development of agrotourism in the region:

- Beskid Śląski, Żywiecki i Mały - in Bielsko-Biała district the villages of Buczkowice, Jaworze, Kozy, Porabka, Wilkowice; in Cieszyn district the villages of Brenna, Goleszów and Istebna; as well as the entire Żywiec district and its rural gminas,

- the area of the Krakow-Częstochowa Hills - in Częstochowa district the villages of Janów, Lelów, Mstów, Olsztyn, Przyrów; in Myszków and Zawiercie district all the rural gminas,

- the area of the Lubliniec Forest and its surroundings (Dąbrowa Zielona, Kamienica Polska, Kłomnice, Konopiska, Kruszyna, Mykanów, Poczesna, Rędziny, Starcza, Rudziniec, Wielowieś, as well as all the rural gminas in districts of Kłobuck, Lubliniec, and Tarnogóra),

- Ziemia Rybnicka, Pilchowice, and all the rural gminas of the Racibórz, Rybnik and Wodzisław districts,

- the area of the vast Pszczyna Forest and the villages of Bestwina, Jasienica, Chybie, Dębowiec, Hażlach, Gierałtowice, as well as Bobrowniki, Mierzęcice, and Psary in the Będzin district. 
Additionally, in line with global standards, agrotourism can be developed in areas that are not formally rural but retain a rural character, in this case they include the towns of Szczyrk, Wisła, Pszczyna and others (Strategia Rozwoju Turystyki..., 2004).

By far the most important event in the Silesia voivodship that brings together tourists and gourmet aficionados alike is the annual food festival Silesian Tastes (Śląskie Smaki). Its first edition took place in Ogrodzieniec, and later it moved on to Cieszyn, Racibórz, Pszczyna, Złoty Potok and Gliwice (Smacznie po Ślasku..., 2017). The festival is organised by the Silesian Tourism Organisation, one of the most active DMOs in Poland. The family-friendly event showcases the vast variety of the Silesian culture and culinary traditions, heritage crafts and arts, and includes a chef teams' competition. The overall ambition of the festival organisers is to promote Silesian gastronomy, local customs and traditional recipes to the widest possible audience. The festival also actively encourages spillover events in restaurants throughout the Silesian voivodship, and is typically accompanied by traditional music and dance shows by folk artists, including the world famous dance and song assembly „Ślask”.

The cooking competition staged during the festival is organised in two categories, for amateur and professional teams. The best team is awarded the title of an Expert of Silesian Tastes and the first three winning teams receive a Golden, Silver and Bronze Sieve, respectively. Ever since the $5^{\text {th }}$ edition of the festival it is also accompanied by a competition for the best homemade liquor based on locally sourced ingredients. The are no strict rules as per the mixture content, and the only limitation is the makers' imagination; every entrant can propose up to three liquors for sampling.

\section{Conclusions}

Most regional cultures have the potential to become tourist attractions. It is especially true with regard to regions characterised by distinctive cultural features, tangible and intangible. Regional cuisine is an example of a cultural asset that can not only attract gourmet-oriented tourists but it can also assist in the promotion of the region. Numerous examples show that gastronomy can play a key role in tourism development as it responds to the natural need of every traveller to quench their thirst and satisfy their hunger during their journey and their stay in the chosen destination. Moreover, living culinary traditions can also enhance the tourist's experience by creating an opportunity for the visitor to get intimately close to the local cultural and natural heritage.

It is also notable that the use of local culinary traditions and foods produced using locally sourced ingredients fits in with the European Commission's objective to promote cultural variety of the Union, and to strengthen regional identities of the member countries. Agroutourism seems to be one of the most suitable means of doing so with regard to rural communities. Also, the preservation and popularisation of local foods and culinary traditions is one of the more effective methods of protecting cultural heritage and local biodiversity.

\section{Referencers}

Dębniewska, M., Tkaczuk, M. (eds.) (1997). Agroturystyka, koszty, ceny, efekty. Warszawa: Poltext. Hjalager, A-M., Richards, G. (eds.) (2002). Tourism and Gastronomy. London: Routledge.

Jęczmyk, A., Maćkowiak, M., Uglis, J. (2014). Dziedzictwo kulinarne elementem przewagi rynkowej w ofercie gospodarstw agroturystycznych. Roczniki Naukowe, 2 (XVI).

Krupa, J. (2016). Regionalne produkty atrakcją turystyki wiejskiej, w tym agroturystyki. In: J. Krupa (ed.), Woda, żywność, turystykaregionalne uwarunkowania zrównoważonego rozwoju obszarów południowo-wschodniej Polski (pp. 29-51). Rzeszów: Edytorial.

Krupa, J., Soliński, T. (2009). Ekonomiczne i organizacyjne aspekty rozwoju turystyki. Rzeszów: WSliz. 
Kryński, Z. (2003). Stan rozwoju bazy turystycznej w gospodarstwach agroturystycznych Regionu Karpackiego i Gór Świętokrzyskich. Ekonomika Rolnictwa, 1 (9), 125-142.

Kuźniar, W. (2010). Rola produktów tradycyjnych w rozwoju usług agroturystycznych (na przykładzie województwa podkarpackiego). Acta Scientiarum Polonorum. Oeconomia, 4 (9), 245-255.

Niedźwieńska, A., Stonowska, B., Kantor, E., Sawiński, P., Zmyślony, M. (2008). Kierunki rozwoju turystyki dla Województwa Małopolskiego na lata 2008-2013. Kraków: UM WM.

Orłowski, D. (2016). Edukacja kulinarna w gospodarstwach agroturystycznych. In: S. Graja-Zwolińska, A. Spychalska, K. Kasprzak (ed.), Turystyka wiejska. Zagadnienia przyrodnicze i kulturowe (pp. 107-122). Poznań: Wieś Jutra.

Puciato, D., Woś, B. (2011). Innowacje jako forma wzbogacenia oferty wybranych gospodarstw agroturystycznych w górach świętokrzyskich. Folia Pomeranae Universitatis Technologiae Stetinensis. Oeconomica, 64 (288), 113-124.

Smacznie po Śląsku. XI Festiwal Śląskie Smaki. Retrieved from: http://www.slaskiesmaki.pl (5.5.2017).

Strategia Rozwoju Turystyki w Województwie Śląskim na lata 2004-2013 (2004). Katowice: SWŚ.

Sznajder, M., Przezbórska, L. (2006). Agroturystyka. Warszawa: PWE.

Tomczyk-Miczka, E. (2007). Małopolska - palce lizać. Kraków: MOT.

Woźniczko, M., Orłowski, D. (2009). Kuchnia ludowa jako regionalny produkt agroturystyczny Podkarpacia. In: P. Palich (ed.), Marka wiejskiego produktu turystycznego (pp. 140-149). Gdynia: AM.

Cite this anticle aS: Dominik, P., Grochowicz, J., Koskowski, M. (2017). The influence of regional culinary traditions on the attractiveness of agrotourism offer. European Journal of Service Management, 4 (24), 11-10. DOI: 1.18276/ejsm.2017.24-01. 